\title{
STRATEGI PENGELOLAAN WARISAN BUDAYA BERBASIS PERAN MASYARAKAT DI KECAMATAN LASEM KABUPATEN REMBANG
}

\author{
Riris Purbasari \\ Balai Pelestarian Cagar Budaya Jawa Tengah \\ Penulis Korespondensi e-mail : ririspurbasari7272@gmail.com
}

\begin{abstract}
Lasem is one of Sub Districts in Rembang Regency located in north coast of central part of Java Island. The strategic position of Lasem that is located on maritime and over-land trading route has made this area since 500 BC inhabited and has passed many different periods of human settlement ranging from prehistory, classic (Hinduism-Buddhism), Islam, colonial periods and until today. That long period of human settlements has left for us now heritages of various cultural influences including Javanese, Chinese, European, Hinduism-Buddhism, and Islamic culture. Heritage is finite and un-renewable in its nature so that it needs to be managed in order to outlive and to be inherited to the next generations. In Lasem, people have been relatively aware of that. Communities in Lasem represented by their organizations have their agendas of appreciating and preserving their heritage. However, they did them individually or not in good coordination of each other. The situation then generates an idea of coordinating activities done by communities in Lasem. Active role of those communities have to be guided and developed so that the purpose of appreciating and preserving their heritage can be achieved. This is intended as for management of heritage can be done continually.
\end{abstract}

Key words: Lasem, Heritage, Heritage Management, Community based

\begin{abstract}
ABSTRAK
Lasem adalah sebuah kecamatan di Kabupaten Rembang yang terletak di pesisir utara Pulau Jawa bagian tengah. Lasem memiliki potensi luar biasa antara lain terletak di jalur perdagangan laut dan darat yang telah didiami sejak 500 tahun Sebelum Masehi diawali oleh manusia masa prasejarah, klasik, Islam, kolonial, hingga saat ini. Masa hunian manusia yang panjang di Lasem meninggalkan warisan budaya dengan berbagai pengaruh budaya diantaranya Jawa, Cina, Eropa, Klasik, dan Islam yang sebagian masih dapat dijumpai hingga saat ini. Namun demikian, warisan budaya bersifat terbatas dan tidak dapat diperbaharui sehingga perlu untuk dikelola agar berusia lebih panjang agar dapat diwariskan kembali kepada generasi selanjutnya. Pengelolaan warisan budaya yang dilakukan oleh masyarakat Lasem selama ini masih bersifat terpisah-pisah satu sama lain. Namun, peran aktif masyarakat terus dibina dan ditingkatkan agar tujuan pengelolaan warisan budaya yang berbasis masyarakat dapat segera dicapai. Pemilihan pengelolaan oleh masyarakat setempat bertujuan agar pengelolaan yang dilakukan dapat berkelanjutan.

Kata Kunci: Lasem, Pengelolaan, Warisan Budaya, Basis Masyarakat.
\end{abstract}


Jurnal Planologi Vol. 15, No. 2, Oktober 2018

Available : http://jurnal.unissula.ac.id/index.php/psa

\section{PENDAHULUAN}

Strategi adalah rencana yang cermat mengenai kegiatan untuk mencapai sasaran khusus (Kridalaksana, 1996). Pengelolaan adalah upaya terpadu untuk melindungi, mengembangkan, dan memanfaatkan Cagar Budaya melalui kebijakan pengaturan perencanaan, pelaksanaan, dan pengawasan untuk sebesar-besarnya kesejahteraan rakyat (Pasal 1 Nomor 21, Undang-Undang Republik Indonesia Nomor 11 Tahun 2010 tentang Cagar Budaya). Pengelolaan yang dimaksud untuk melakukan upaya terpadu untuk melindungi, mengembangkan, dan memanfaatkan warisan budaya.

Warisan Budaya dapat diartikan sebagai suatu yang dilestarikan dari generasi masa lalu kemudian diwariskan kepada generasi sekarang, yang kemudian akan mewariskannya untuk generasi yang akan datang (Aksa, 2004: 1), Warisan budaya mencakup bidang yang sangat luas karena seluruh karya manusia merupakan budaya. Warisan budaya yang ada di Kecamatan Lasem terdiri dari tangible dan intangible. Upaya pengelolaan warisan budaya yang ditawarkan dalam tulisan ini dilakukan dengan berbasis masyarakat. Berbasis masyarakat berasal dari dua kata yaitu berbasis dan masyarakat. Berbasis berasal dari kata basis yang artinya asas atau dasar (Kridalaksana, 1996). Sementara masyarakat adalah sejumlah manusia dalam arti seluas-luasnya dan terikat oleh suatu kebudayaan yang mereka anggap sama (Kridalaksana, 1996). Berbasis masyarakat dapat diartikan sebagai gerakan yang dilakukan oleh masyarakat atau dengan kata lain masyarakat sebagai pelaku utamanya dalam upaya pengelolaan warisan budaya di Lasem.

Lasem adalah Kota Kecamatan yang ada di wilayah Kabupaten Rembang. Secara

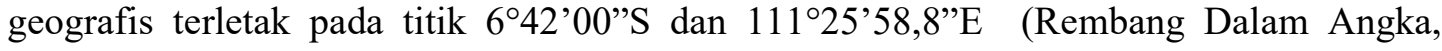
2017). Wilayah penelitian dibatasi pada Kota Kecamatan Lasem yang memiliki batas Laut Jawa di sebelah utara, Kecamatan Sluke di sebelah timur, Kecamatan Pancur di sebelah selatan, dan Kecamatan Rembang di sebelah barat dengan luas wilayah 4504 ha yang terdiri dari lingkungan pesisir, dataran, dan pegunungan. Lingkungan pesisir berada di bagian utara memanjang dari barat hingga timur, lingkungan pegunungan di sisi timur, dan dataran di sisi selatan-barat (Disbudparpora, 2013: 1). 


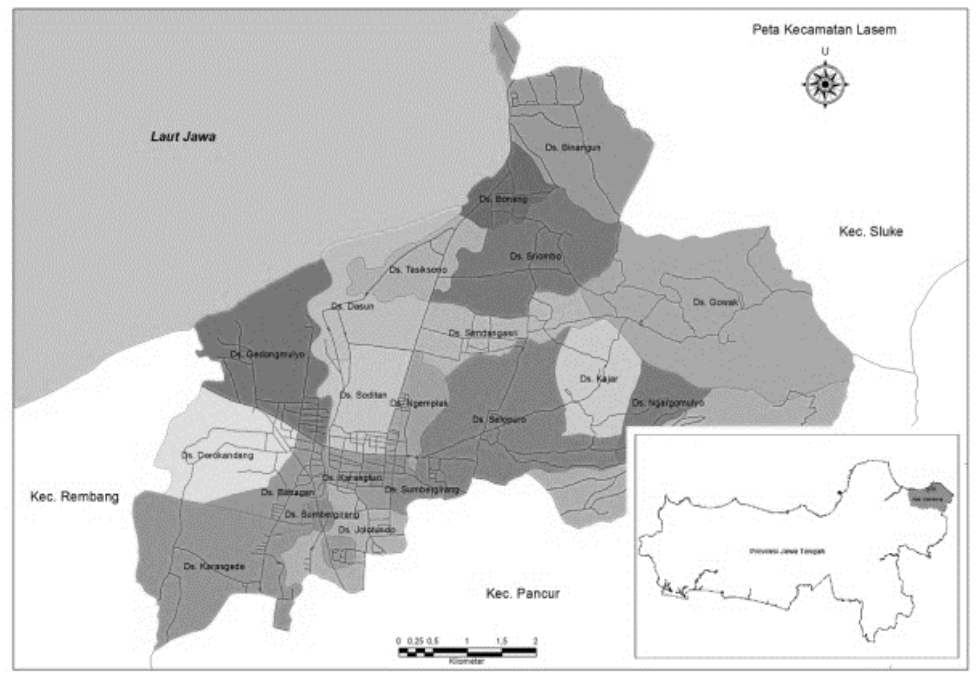

Gambar 1. Peta Kecamatan Lasem Sumber: Peta Rupa Bumi

Letak Kecamatan Lasem berada di pesisir pantai utara Jawa Tengah dengan dilintasi Jalan Daendels yang menghubungkan Pulau Jawa bagian barat dengan bagian timur (Periksa Gambar 2). Selain itu, Kecamatan Lasem juga terletak di antara Pelabuhan Jepara dan Pelabuhan Tuban. Hal inilah yang menjadikan Kecamatan Lasem sebagai wilayah yang strategis karena berada di jalur perdagangan darat maupun laut (Utomo, 2009). Letaknya yang strategis menyebabkan Kecamatan Lasem disinggahi banyak pendatang baik dari dalam maupun luar negeri dengan aktivitas perdagangan yang cukup ramai (Utomo, 2009).

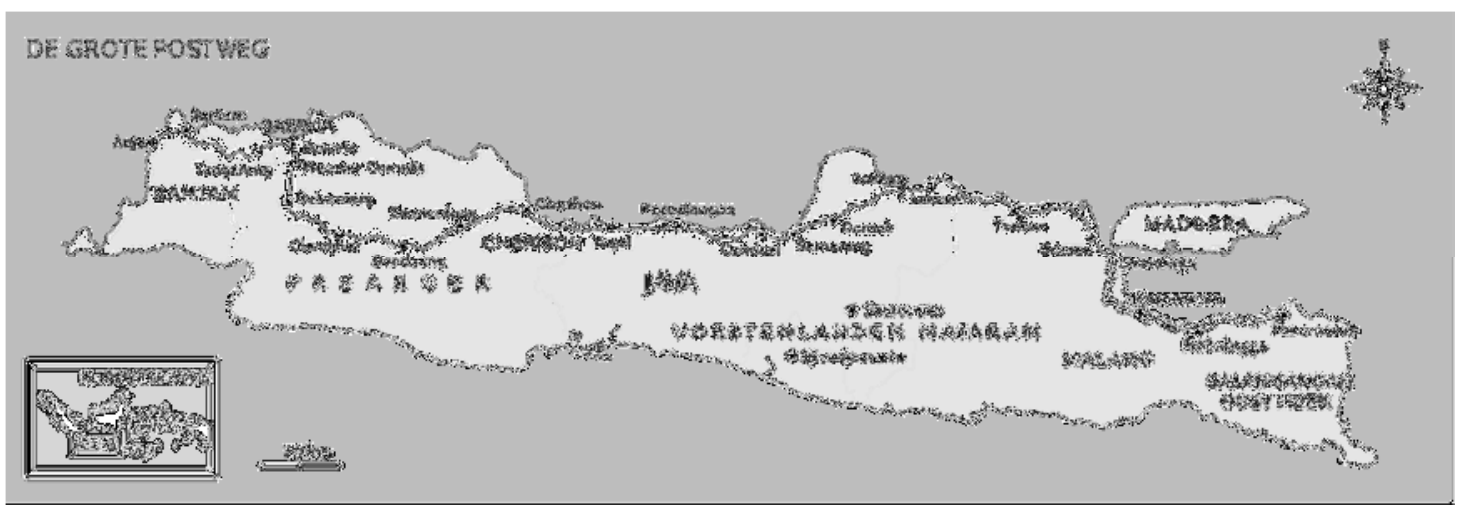

Gambar 2. Peta Jalan Daendels (De Grote PostWeg). Sumber: nl.wikimedia.org

Aktivitas perdagangan mempertemukan pedagang dan pembeli baik asing maupun lokal. Interaksi antar pedagang dan pembeli lambat laun disertai dengan adanya interaksi 
kebudayaan yang melatar belakangi kehidupan mereka. Adanya interaksi masyarakat lokal dengan para pendatang menyebabkan wilayah ini memiliki kekayaan warisan budaya cukup banyak berasal dari kurun waktu yang sangat panjang. Berdasarkan observasi yang dilakukan penulis, warisan budaya yang masih dapat dilihat saat ini sedikitnya ada tiga pengaruh budaya yaitu Eropa, Cina, dan kebudayaan Islam. Pengaruh Eropa dan Cina terlihat pada pengaruh arsitektur bangunan-bangunan yang ada di Kecamatan Lasem. Pengaruh Cina juga terlihat pada berbagai tradisi yang masih dijalankan oleh sebagian masyarakat Cina di Kecamatan Lasem. Sementara pengaruh kebudayaan Islam terlihat dari adanya pesantren dengan tradisi yang masih dilakukan.

Dari berbagai pengaruh budaya yang masih dapat ditemui, dominasi arsitektur dan aktivitas ritual perayaan keagamaan masyarakat Cina di Kecamatan Lasem menyebabkan munculnya sebutan Petit Chinois yang artinya Cina Kecil. Istilah Petit Chinois pertama kali dilontarkan oleh wisatawan Perancis karena banyaknya tinggalan budaya yang berupa upacara-upacara perayaan keagamaan dan bangunan-bangunan yang berarsitektur Cina (Hartono, 2010: 2). Warisan budaya tangible lainnya yang ada di Kecamatan Lasem antara lain situs masa prasejarah, klasik, Islam, maupun kolonial. Situs masa prasejarah antara lain terdapat di Binangun, Plawangan, Terjan, dan Leran. Situs yang ada di luar wilayah Kecamatan Lasem tidak akan dibahas lebih jauh. Situs masa klasik dapat ditemui di Candi Samodrawela. Situs masa Islam dapat dijumpai berbentuk Masjid Jami' Lasem dan makam-makam yang tersebar di beberapa lokasi. Situs masa kolonial berada di sepanjang Jalan Daendels dan tersebar di beberapa lokasi. Selain warisan budaya tangible, terdapat pula warisan budaya intangible yang terdiri dari keahlian membatik, makanan khas, dan berbagai tradisi yang masih dijalankan oleh beberapa kelompok masyarakat di Kecamatan Lasem. Aktivitas masyarakat yang masih dilakukan berkaitan dengan tradisi, tanpa disadari terus dilakukan dengan pemaknaan ulang terhadap warisan budaya mereka dan hal tersebut merupakan sebuah langkah penting dalam upaya pelestariannya.

Pemaknaan ulang dapat dilihat dari perubahan ritual yang dilakukan pada pelaksanaan berbagai tradisi, misalnya sedekah laut dan sedekah bumi. Selanjutnya, upayaupaya pelestarian dilakukan antara lain dengan meneruskan kebiasaan yang dilakukan turun-temurun oleh para orang tua mereka. Sebagai contoh adalah kepandaian membuat kain dengan motif batik khas Lasem. Contoh lainnya adalah dengan meneruskan tradisi membaca Kitab Badrasanti dengan tembang dan diiringi gambang, salah satu alat musik gamelan. Upaya-upaya lain yang dilakukan oleh masyarakat Kecamatan Lasem terhadap 
warisan budaya mereka adalah dengan membentuk lembaga-lembaga yang peduli terhadap warisan budaya tersebut. Lembaga-lembaga tersebut aktif baik dalam sosialisasi informasi sejarah dan budaya kepada masyarakat maupun tindakan-tindakan advokasi terhadap warisan budaya yang mengalami ancaman pelestarian. Selain itu, mereka juga aktif memperkenalkan kekhasan Kecamatan Lasem melalui warisan budayanya kepada masyarakat luar wilayah. Hal tersebut bukan saja sebagai sebuah langkah yang sifatnya ekonomis dalam pengertian sebagai bumbu daya tarik wisata ke Kecamatan Lasem, namun juga sebagai bagian dari perayaan identitas ke-Lasem-an itu sendiri.

Kesadaran masyarakat untuk meneruskan adat kebiasaan serta ritual yang ada turun-temurun merupakan potensi yang luar biasa untuk dapat digunakan dalam pelestarian peninggalan-peninggalan yang ada baik tangible maupun intangible. Oleh karena itu, permasalahan yang diangkat di dalam penelitian ini adalah: Warisan budaya Kecamatan Lasem saat ini sudah mengalami berbagai ancaman kerusakan dan kepunahan, sehingga perlu segera dilakukan pengelolaan yang dilakukan secara aktif oleh masyarakat setempat. Pertanyaan yang kemudian muncul adalah, strategi pengelolaan seperti apakah yang ideal bagi Kecamatan Lasem yang memiliki karakter warisan budaya yang beragam dengan penduduk yang berasal dari etnis yang beragam?

\section{METODOLOGI}

Penelitian ini merupakan penelitian deskriptif analitis dengan langkah-langkah penelitian sebagai berikut:

a. Mengumpulkan data baik data kesejarahan, arkeologi, maupun data antropologis. Teknik yang digunakan adalah penelusuran pustaka, observasi pada bangunan, situs, serta aktivitas masyarakat, dan wawancara. Wawancara dilakukan dengan narasumber yang mengetahui perjalanan sejarah Lasem, bergerak di bidang pelestarian lokal, dan narasumber lain yang dianggap perlu untuk melengkapi pandangan masyarakat terhadap nilai penting warisan budaya Lasem.

b. Data yang telah diperoleh diklasifikasi sebagai unit analisis. Data yang dianalisis berupa warisan budaya baik tangible maupun intangible dan pelaku aktivitas pelestarian dan pemanfaatan warisan budaya di Kecamatan Lasem antara lain masyarakat setempat, swasta, dan pemerintah.

c. Menyusun analisis nilai penting warisan budaya Lasem kemudian nilai penting tersebut dianalisis SWOT. Analisis ini dilakukan untuk mengetahui Strength 
(kekuatan), Weakness (kelemahan), Opportunity (kesempatan), dan Threath (Ancaman) nilai penting warisan budaya Lasem. Hasil analisis kemudian digunakan untuk mengetahui kekuatan dan peluang sehingga dapat dimaksimalkan agar dapat menghadapi kelemahan dan ancaman terhadap warisan budaya Lasem.

d. Menyusun strategi pengelolaan Lasem yang berkelanjutan dengan berbasis pada masyarakat.

\section{HASIL DAN PEMBAHASAN}

Pelestarian warisan budaya menjadi tanggung jawab bersama antara pemerintah dan masyarakat. Masyarakat sebagai pemilik langsung warisan budaya memiliki peran besar untuk meneruskan warisan tersebut, sehingga peran aktif masyarakat perlu ditingkatkan. Demikian dengan masyarakat di Kecamatan Lasem yang memiliki warisan budaya beragam, terdiri dari tangible dan intangible.

Lasem memiliki sedikitnya 150 -an warisan budaya tangible yang terdiri dari situs, struktur, kawasan, dan bangunan yang tersebar di beberapa bagian wilayah Kecamatan Lasem. Warisan budaya tersebut berasal dari latar belakang masa prasejarah, klasik, islam, dan kolonial. Sebagian besar situs dan struktur dalam kondisi kurang terawat, sementara kawasan dan bangunan-bangunan yang ada masih dalam kondisi penuh ancaman. Hal ini dimunghkinkan masyarakat belum sepenuhnya mengetahui nilai penting yang dimiliki warisan budaya tersebut. Beberapa nilai penting warisan budaya tersebut antara lain:

\section{Nilai Penting Sejarah Dan Kebudayaan}

Nilai penting sejarah dan kebudayaan warisan budaya Lasem terlihat pada sejarah panjang yang terjadi. Lasem dikenal sebagai sebuah permukiman setidaknya sejak 500 tahun Sebelum Masehi. Terdapat dua situs prasejarah yang setidaknya berlangsung pada satu kurun waktu yang sama. Kedua situs tersebut adalah Situs Leran dan Situs. Berdasar temuan di keempat situs tersebut, didapatkan informasi bahwa masyarakat penghuni Lasem pada masa prasejarah berasal dari ras Mongoloid penutur bahasa Austronesia berasal dari masa Paleo Metalik (Kasnowihardjo, 2013). Keempat situs prasejarah yang ada di Lasem dapat memberikan informasi bahwa Lasem merupakan wilayah yang cocok untuk menjadi tempat bermukim pada masa tersebut. Kehidupan masyarakat Lasem terus berjalan seiring dengan pergantian masa dalam sejarah. Ketika bentuk kerajaan dikenal pada masa klasik, Lasem merupakan salah satu mandala Kerajaan Majapahit. Mandala adalah daerah perdikan dengan pemerintahan sendiri (Hardjowardojo, 1965). Terdapat delapan daerah mandala yaitu Kahuripan, Tumapel, Paguhan, Wengker, Daha, Lasem, 
Pajang, dan Kabalan (Hardjowardojo, 1965). Sebagai salah satu mandala Kerajaan Majapahit, Lasem diperintah oleh Bhre Lasem yang merupakan salah satu bagian Paduka Battara Sapta Prabhu atau dewan pertimbangan agung Kerajaan Majapahit (Hardjowardojo, 1965) . Lasem sebagai salah satu mandala yang dipimpin langsung oleh salah satu keluarga dekat Raja, menunjukkan bahwa Lasem memiliki posisi cukup penting bagi Kerajaan Majapahit. Posisi Lasem yang berada di daerah strategis menjadikannya sebagai pusat perdagangan di wilayah Pulau Jawa bagian tengah utara. Posisi ini dapat dibuktikan dengan adanya tinggalan berupa bekas dermaga di tepi Sungai Babagan dan beberapa titik kapal karam (Purbasari, 2011). Keberadaan pelabuhan juga merupakan salah satu petunjuk pentingnya Lasem bagi Majapahit. Hal ini terlihat dengan jabatan syahbandar yang dipegang langsung oleh suami Bhre Lasem (Riana, 2009.). Pelabuhan Lasem merupakan pelabuhan perdagangan yang cukup besar. Selain sebagai pelabuhan perdagangan, juga digunakan sebagai tempat bersandar junk-junk armada perang Majapahit yang dipimpin oleh Bhre Matahun (Utomo, 2009).

Saat pengaruh Kerajaan Majapahit mulai menurun seiring dengan masuk dan berkembangnya agama Islam, Lasem menjadi satu daerah merdeka. Saat itu, kerajaan Islam yang memiliki kekuasaan cukup besar dengan wilayah yang luas adalah kerajaan Demak Bintoro. Lasem menjadi sebuah daerah yang merdeka di luar kekuasaan Kerajaan Demak (Pratiwo, 2010). Lasem memiliki keterkaitan dengan kerajaan Demak Bintoro karena diyakini nenek buyut Sultan Trenggono berasal dari Lasem (Karsono, 1920). Namun pada saat pusat kerajaan Islam berpindah ke Mataram, Lasem berada di bawah kekuasaan Mataram pada tahun 1664 Masehi setelah ditahklukkan oleh Sultan Agung. Meskipun menjadi wilayah bawahan, Lasem tetap menjadi daerah perdagangan yang ramai dan penting (Kwan, 2010). Lasem muncul pada beberapa catatan harian VOC, dituliskan beberapa peristiwa penting yang terjadi di Lasem. Peristiwa penting yang berkaitan dengan Lasem adalah berkuasanya Sunan Mataram atas Lasem dan Kendal pada tahun 1664 (Graaf, 1987). Peristiwa lain yang masuk dalam catatan mengenai pengangkatan pejabat syahbandar pada tahun 1669-1670 Masehi (Graaf, 1987). Peristiwa lain adalah tunduknya Bupati Lasem dan Juwana kepada para perompak Makassar pada tahun 1676 Masehi (Graaf, 1987). Sejak saat itu, Lasem menjadi satu bandar yang digunakan oleh pemberontak Makassar untuk berangkat ke berbagai daerah (Graaf, 1987). Peristiwa lain yang masuk dalam catatan harian VOC tentang Lasem berkaitan dengan pengangkatan pejabat syahbandar pada tahun 1670 (Graaf, 1987). Syahbandar adalah salah satu jabatan 
yang ada di sistem pengaturan sebuah pelabuhan. Jabatan ini muncul dan ada sejak masa Majapahit. Hal ini menunjukkan adanya sebuah pelabuhan yang cukup besar dan ramai mengingat pejabatnya ditunjuk langsung oleh penguasa tertinggi sebuah wilayah kekuasaan (Graaf, 1987: 201-220).

Ramainya Lasem sebagai pusat perdagangan dan perlawanan masyarakat Lasem kepada Kumpeni, menyebabkan VOC membangun benteng pertahanan di daerah Tulis (Pratiwo, 2010). Perlawanan masyarakat Lasem dapat dipatahkan oleh Kumpeni dan sebagai akibatnya status Lasem diturunkan menjadi Kecamatan (Pratiwo, 2010). Pusat pemerintahan selanjutnya dipindahkan ke Rembang. Meskipun tak lagi menjadi wilayah pusat pemerintahan, Lasem tetap menjadi pusat keramaian dengan aktivitas ekonomi dan perdagangan, Lasem menjadi semakin ramai dengan dibangunnya jalan kereta api yang menghubungkan Lasem dengan daerah pedalaman (Kwan, 2010). Pembangunan jalan kereta api tidak lepas dari pembangunan pabrik gula di wilayah Lasem, namun pada tahun 1986 jalur kereta api ditutup (Kwan, 2015).

Seiring dengan itu, Lasem berangsur menjadi kota yang sepi. Lasem mulai ditinggalkan sebagian penduduknya karena generasi muda lebih suka merantau ke kota lain yang lebih ramai. Kebiasaan merantau ini menjadikan salah satu sebab banyaknya bangunan yang ditinggalkan kosong tanpa penghuni.

2. Nilai Penting Ilmu Pengetahuan

Nilai penting ilmu pengetahuan yang dapat disumbangkan oleh warisan budaya Lasem antara lain: Bidang ilmu Arkeologi misalnya, warisan budaya Lasem dapat diteliti lebih lanjut untuk menjawab permasalahan dan mengkonfirmasi teori-teori tentang proses masuk dan berkembangnya pengaruh budaya asing di Nusantara. Dengan mengetahui unsur asing yang ada di Lasem, dapat diketahui pula unsur asli kebudayaan Nusantara. Pada bidang ilmu Antropologi, warisan budaya yang ada di Lasem dapat menjawab permasalahan perubahan budaya dalam jangka waktu tertentu. Warisan budaya Lasem dapat juga menjawab interaksi antara etnis Jawa, Cina, dan Arab yang hingga saat ini hidup rukun berdampingan di Lasem. Keharmonisan masyarakat Lasem yang terlihat saat ini tidak lepas dari pengalaman sejarah yang terjadi.

Bagi bidang ilmu Arsitektur dan Teknik Sipil, warisan budaya Lasem yang berupa bangunan dapat diteliti lebih lanjut. Penelitian bidang ilmu ini untuk menjawab permasalahan bahan dan teknologi pembangunannya. Bahan bangunan yang digunakan memiliki tingkat keawetan tinggi mengingat umur bangunan yang ada di Lasem sudah 
ratusan tahun dan kondisi saat ini relatif masih bagus, terutama balok-balok kayu jati yang berniai tinggi. Bahan bangunan yang masih awet hingga saat ini tentunya menarik untuk diteliti lebih jauh kualitas dan teknik pengawetan yang dikenal pada masa lalu. Selain itu, dapat juga diteliti untuk mendapat jawaban teknik pembangunan bangunan di daerah pesisir.

Bidang ilmu lainnya misalnya seni kriya yang dapat mengkaji lebih jauh tentang teknik pembuatan ornamen-ornamen pada bangunan dari berbagai jenis bahan dan motif. Selain itu, dapat juga menelusuri sejarah motif kain batik yang kini menjadi salah satu ciri khas batik Lasem.

\section{Nilai Penting Pendidikan}

Nilai penting pendidikan didasarkan pada potensi warisan budaya Lasem untuk dikembangkan menjadi sarana pendidikan bagi masyarakat dan cara penelitiannya. Pendidikan yang telah dilakukan oleh sebagian masyarakat Lasem adalah dengan memasukkan pembacaan Babad Badra Santi dengan cara dilagukan (ditembangkan) diiringan gambang, dilakukan pada kegiatan luar sekolah tingkat SMU Warisan budaya Lasem juga dapat dimasukkan menjadi muatan lokal pada pelajaran sejarah untuk para siswa mulai tingkat dasar hingga tingkat menengah di Lasem. Di samping itu, nilai penting pendidikan juga merupakan penyampaian informasi dari generasi ke generasi berikutnya mengenai sejarah lingkungan tempat tinggal mereka. Hal ini sekaligus untuk menanamkan kesadaran identitas kelompok mereka yang memiliki warisan budaya beragam dan berbeda dari daerah lain.

\section{Nilai Penting Ekonomi}

Nilai penting ekonomi didasarkan pada kemampuan warisan budaya Lasem untuk dapat memenuhi kebutuhan hidup masyarakatnya dalam bidang ekonomi. Pemenuhan kebutuhan ekonomi masyarakat Lasem dapat dilakukan dengan menggiatkan peran masyarakat sebagai pelaku utama penyelenggara pariwisata. Upaya ini diawali dengan melibatkan masyarakat dalam pengelolaan warisan budaya setempat. Pengelolaan juga memanfaatkan bangunan-bangunan rumah mereka sebagai penginapan atau home stay mengingat jumlah hotel yang ada di Lasem masih terbatas. Lasem hanya memiliki dua hotel dengan kelas melati. Pemanfaatan rumah sebagai home stay dapat menambah pendapatan masyarakat dan sekaligus memanfaatkan bangunannya. Di samping itu,

pemenuhan terhadap permintaan batik sebagai tanda mata khas memungkinkan untuk menyediakan lapangan kerja bagi masyarakat Lasem. 
Nilai penting ekonomi lainnya dapat diperoleh dari memanfaatkan keahlian membuat batik khas Lasem. Saat ini Lasem identik sebagai kota batik. Salah satu batik yang dikenal sebagai batik Lasem adalah "Batik Tiga Negeri". Selain batik tersebut, terdapat ciri khas yang tidak ditemukan di daerah lain yaitu "Bang bangan Getih Pitik" dan motif perpaduan antara tradisional dan Cina.

\section{Nilai Penting Religi}

Religi adalah kepercayaan akan adanya kekuatan di atas manusia (Kridalaksana, 1996). Animisme dan dinamisme termasuk dalam pengertian religi (Kridalaksana, 1996). Masyarakat Lasem telah mengenal religi sejak masa prasejarah dengan tradisi megalitikumnya. Religi masa prasejarah dapat dilihat dari tinggalan bendawi yang berupa bangunan-bangunan megalitik di Situs Terjan. Saat masuk dan berkembangnya agama Hindu dan Buddha pada masa yang hampir bersamaan, masyarakat Lasem juga melakukan ritual sesuai kepercayaan mereka. Hal ini dapat dilihat dari tinggalan lingga dan bekas Candi Samodrawela. Candi Samodrawela adalah nama yang diberikan masyarakat setempat untuk menyebut runtuhan bata yang ada di Desa Caruban. Selain itu juga dapat diketahui dari sebutan Dewi Kwan Im untuk Dewi Indu .

Pengaruh agama Islam juga masuk dan berkembang di Lasem. Hal ini dapat dilihat dari tinggalan masjid dan makam tokoh-tokoh yang berperan pada penyebaran agama Islam di Lasem. Selain itu terlihat juga pada pesantren-pesantren yang ada di Lasem. Setelah era perkembangan agama Islam, masuklah pengaruh agama Kristen yang dibawa oleh orang-orang Belanda yang masuk ke Lasem. Pengaruh agama Kristen masih dapat dijumpai dengan adanya bangunan gereja, sekolah kristen, dan sebagian masyarakat yang memeluk agama tersebut. Selain agama-agama tersebut, sebagian masyarakat Cina yang ada di Kecamatan Lasem masih memeluk agama Kong $\mathrm{Hu} \mathrm{Cu}$. Agama ini merupakan agama kepercayaan leluhur dari negri Cina yang masih dipegang teguh oleh sebagian masyarakat Cina di Lasem. Pengaruh enam agama masih berkembang bersama di Kecamatan Lasem hingga saat ini. Namun perbedaan keyakinan serta ritual yang dilakukan tidak menyebabkan gesekan diantara para pemeluknya. Hal ini dipengaruhi juga oleh tekat masyarakat Lasem yang tetap menjaga keharmonisan hidup bersama.

Berdasarkan pada uraian tersebut di atas, dapat diketahui bahwa warisan budaya Kecamatan Lasem memiliki nilai penting. Nilai penting masing-masing warisan budaya dapat dirangkum di dalam tabel sebagai berikut: 
Tabel 1: Tabel Nilai Penting Warisan Budaya Kecamatan Lasem

\begin{tabular}{|l|l|l|l|l|l|l|}
\hline No & Nama & NPSK & NPIP & NPP & NPE & NPR \\
\hline 1 & Situs Leran & V & V & V & - & V \\
\hline 2 & Situs Binangun & V & V & V & - & V \\
\hline 3 & Runtuhan Candi Samodrawela & V & V & V & - & V \\
\hline 4 & Puri Kriyan & V & V & V & V & - \\
\hline 5 & $\begin{array}{l}\text { Sumur Kuno dan Sebaran Pecahan } \\
\text { Keramik }\end{array}$ & V & V & V & - & - \\
\hline 6 & Masjid Jami' Lasem & V & V & V & V & V \\
\hline 7 & Makam Mbah Sambu & V & V & V & - & V \\
\hline 8 & Makam Nyi Ageng Malokhah & V & - & V & - & V \\
\hline 9 & Makam Adipati Tejakusuma I & V & - & V & - & V \\
\hline 10 & Makam Santi Puspa & V & - & V & - & V \\
\hline 11 & Makam Keluarga Bupati Tuban & V & - & V & - & V \\
\hline 12 & Kawasan Soditan & V & V & V & V & V \\
\hline 13 & Kawasan Gedong Mulyo & V & V & V & V & V \\
\hline 14 & Kawasan Karangturi & V & V & V & V & V \\
\hline 15 & Bong Cina & V & V & - & - & V \\
\hline 16 & Bekas Stasiun Kereta Api & V & V & V & V & - \\
\hline 17 & Bekas Galangan Kapal Dasun & V & V & V & - & - \\
\hline 18 & Bekas Markas Belanda & V & V & V & - & - \\
\hline 19 & Batik Lasem & V & V & V & V & - \\
\hline 20 & Lontong Tuyuhan & V & - & - & V & - \\
\hline 21 & Tradisi Cina & V & V & V & V & V \\
\hline 22 & Tradisi Jawa & V & V & V & V & V \\
\hline 23 & Tradisi Islam-Jawa & V & V & V & V & V \\
\hline
\end{tabular}

Sumber: Analisis Penulis, 2018

Catatan:

NPSK : Nilai Penting Sejarah dan Kebudayaan

NPIP : Nilai Penting Ilmu Pengetahuan

NPP : Nilai Penting Pendidikan

NPE : Nilai Penting Ekonomi

NPR : Nilai Penting Religi

Berdasarkan pada nilai penting yang ada perlu dilakukan analisis SWOT (Strengths, Weakness, Opportunity, Threats). Nilai penting yang dimiliki oleh warisan budaya Lasem juga memiliki kekuatan, kelemahan, ancaman, dan kesempatan yang diuraikan sebagai berikut:

Tabel 2: Analisi SWOT Nilai Penting Warisan Budaya

\begin{tabular}{|l|l|l|l|}
\hline No. & Kekuatan (Strengths) & No. & Kelemahan (Weakness) \\
\hline 1. & Nilai Penting Sejarah dan Kebudayaan & & \\
\hline & $\begin{array}{l}\text { Lasem merupakan tempat bersejarah yang } \\
\text { memiliki hubungan dengan kekuasaan } \\
\text { Majapahit, Demak, Mataram Islam, } \\
\text { hingga NKRI. }\end{array}$ & $\begin{array}{l}\text { Sebagian besar masyarakat Lasem } \\
\text { belum mengenal sejarah Lasem yang } \\
\text { panjang dan beragam. }\end{array}$ \\
\cline { 2 - 3 } & $\begin{array}{l}\text { Sebagian masyarakat Lasem belum } \\
\text { mengenal tokoh-tokoh penting dalam } \\
\text { sejarah Lasem }\end{array}$ \\
\hline $\begin{array}{l}\text { Temuan situs dan tinggalan arkeologis } \\
\text { yang cukup banyak dan beragam. }\end{array}$ & $\begin{array}{l}\text { Banyak situs dan tinggalan arkeologis } \\
\text { yang telah rusak dan hilang. }\end{array}$ \\
\hline
\end{tabular}


Jurnal Planologi Vol. 15, No. 2, Oktober 2018

Available : http://jurnal.unissula.ac.id/index.php/psa

\begin{tabular}{|c|c|c|}
\hline \multirow[t]{3}{*}{2.} & \multicolumn{2}{|l|}{ Nilai Penting Ilmu Pengetahuan } \\
\hline & \multirow{2}{*}{$\begin{array}{l}\text { Arsitektur } \\
\text { - Terdapat sedikitnya empat pengaruh } \\
\text { gaya arsitektur bangunan di Lasem yaitu } \\
\text { Eropa, Tiongkok, Tradisional Jawa, dan } \\
\text { Indis. } \\
\text { - Bahan bangunan yang bermutu tinggi. }\end{array}$} & $\begin{array}{l}\text { Banyak bangunan yang telah rusak dan } \\
\text { sebagian hilang karena pembangunan. }\end{array}$ \\
\hline & & $\begin{array}{l}\text { Maraknya pembelian bangunan kuno } \\
\text { yang kemudian hanya diambil bagian } \\
\text { kayu yang ada pada bangunan. }\end{array}$ \\
\hline & \multirow{2}{*}{$\begin{array}{l}\text { Arkeologi } \\
\text { - Kerangka manusia dengan aktivitas } \\
\text { modifikasi bentuk gigi. Diketahui dari } \\
\text { ras Mongoloid penutur bahasa } \\
\text { Austronesia. } \\
\text { - Framen keramik asing, berasal dari } \\
\text { China dan Eropa yang ditemukan dalam } \\
\text { jumlah banyak. }\end{array}$} & $\begin{array}{l}\text { Situs temuan manusia prasejarah yang } \\
\text { sudah tidak dapat dikenali karena } \\
\text { berubah menjadi permukiman. }\end{array}$ \\
\hline & & $\begin{array}{l}\text { Fragmen keramik asing sudah banyak } \\
\text { berkurang di beberapa daerah sebaran } \\
\text { karena dipungut dan dibawa pergi oleh } \\
\text { pengunjung. }\end{array}$ \\
\hline \multirow[t]{3}{*}{3.} & \multirow{3}{*}{$\begin{array}{l}\text { Nilai Penting Pendidikan } \\
\text { - Maca Pat (nama lain nembang atau } \\
\text { bernyanyi dalam kebudayaan Jawa) dan } \\
\text { ketrampilan membatik masuk ke dalam } \\
\text { kegiatan luar sekolah tingkat SMU } \\
\text { - Pendidikan tentang tradisi-tradisi yang } \\
\text { ada di Lasem dapat dimasukkan ke } \\
\text { dalam kegiatan belajar mengajar di } \\
\text { sekolah. } \\
\text { - Tokoh-tokoh sejarah lokal yang dapat } \\
\text { dimasukkan dalam muatan lokal } \\
\text { kurikulum sekolah. } \\
\text { - Terbangunnya rasa bangga memiliki } \\
\text { identitas sebagai masyarakat Lasem }\end{array}$} & \\
\hline & & $\begin{array}{l}\text { Belum ada kebijakan dari Kepala } \\
\text { Dinas Pendidkan dan kebudayaan } \\
\text { untuk memberlakukan muatan lokal } \\
\text { dalam kurikulum setempat. }\end{array}$ \\
\hline & & $\begin{array}{l}\text { Kurangnya tenaga pengajar dengan } \\
\text { kemampuan yang memadai tentang } \\
\text { kebudayaan tradisional. }\end{array}$ \\
\hline \multirow[t]{4}{*}{4.} & Nilai Penting Ekonomi & \\
\hline & \multirow{3}{*}{$\begin{array}{l}\text { - Batik Lasem dengan motif khas bernama } \\
\text { Batik Tiga Negeri berharga sangat tinggi } \\
\text { - Tersedianya lapangan pekerjaan dari } \\
\text { sektor industri batik } \\
\text { - Bangunan kuno rumah tinggal dapat } \\
\text { dijadikan home stay (wisma tamu) atau } \\
\text { untuk aktivitas lainnya. } \\
\text { - Tersedianya lapangan pekerjaan di } \\
\text { bidang kuliner. }\end{array}$} & $\begin{array}{l}\text { Proses produksi yang memerlukan } \\
\text { waktu lebih lama karena harus } \\
\text { dikerjakan di tiga kota dengan biaya } \\
\text { yang cukup tinggi mengakibatkan } \\
\text { ketersediaan batik Tiga Negeri yang } \\
\text { kurang memadai. }\end{array}$ \\
\hline & & $\begin{array}{l}\text { Banyak kaum muda yang lebih } \\
\text { memilih jadi buruh pabrik besar. }\end{array}$ \\
\hline & & $\begin{array}{l}\text { Kurangnya sarana penunjang } \\
\text { bangunan kuno yang digunakan } \\
\text { sebagai home stay atau wisma tamu. }\end{array}$ \\
\hline \multirow[t]{3}{*}{5.} & Nilai Penting Religi & \\
\hline & $\begin{array}{l}\text { Warisan budaya yang ada di Lasem } \\
\text { menggambarkan perkembangan religi } \\
\text { diawali dengan masa Prasejarah dengan } \\
\text { pemujaan pada leluhur dan } \\
\text { meninggalkan bangunan-bangunan } \\
\text { Megalitik, Hindu-Buddha, Kong Hu Cu, } \\
\text { Islam hingga Kristen dan Katholik. }\end{array}$ & $\begin{array}{l}\text { Perubahan gaya hidup yang serba } \\
\text { praktis pada masyarakat saat ini. Hal } \\
\text { ini berimbas pada penyederhanaan } \\
\text { ritual dan tradisi dengan aktivitas dan } \\
\text { perlengkapan yang dianggap lebih } \\
\text { praktis dan efisien. }\end{array}$ \\
\hline & & $\begin{array}{l}\text { Kurangnya fasilitas dari Pemerintah } \\
\text { Daerah dalam pelaksanaan ritual dan } \\
\text { tradisi. }\end{array}$ \\
\hline
\end{tabular}




\begin{tabular}{|l|l|l|l|}
\hline No. & Peluang (Opportunity) & No. & Ancaman (Threats) \\
\hline 1. & $\begin{array}{l}\text { Kesadaran sebagian masyarakat } \\
\text { Lasem akan nilai penting warisan } \\
\text { budaya. }\end{array}$ & 1. & $\begin{array}{l}\text { Pemerintah kurang memanfaatkan } \\
\text { dan mengarahkan kegiatan } \\
\text { masyarakat dalam upaya } \\
\text { pelestarian. }\end{array}$ \\
\hline 2. & $\begin{array}{l}\text { Lasem mudah dicapai dari kota besar } \\
\text { seperti Semarang dan Surabaya } \\
\text { dengan berbagai moda transportasi. }\end{array}$ & 2. & $\begin{array}{l}\text { Terbatasnya jenis transportasi } \\
\text { umum dari kota-kota besar terdekat } \\
\text { menuju Lasem. }\end{array}$ \\
\hline 4. & $\begin{array}{l}\text { Tersedia penginapan dan rumah } \\
\text { makan 4. }\end{array}$ & $\begin{array}{l}\text { Sarana penginapan dan rumah } \\
\text { makan yang ada di Lasem belum } \\
\text { mendukung pada isu pelestarian } \\
\text { dan pemanfaatan warisan budaya } \\
\text { Lasem. komunikasi, }\end{array}$ \\
\hline 5. & $\begin{array}{l}\text { Tersedia sarana k. } \\
\text { transportasi, kesehatan, keamanan, dan } \\
\text { bank }\end{array}$ & $\begin{array}{l}\text { Sarana komunikasi, kesehatan, dan } \\
\text { perbankan belum terintegrasi } \\
\text { dengan baik. }\end{array}$ \\
\hline 6. & $\begin{array}{l}\text { Tersedianya air bersih } \\
\text { Kurangnya alternatif moda } \\
\text { transportasi umum yang } \\
\text { menjangkau Lasem dari kota-kota } \\
\text { besar terdekat (Semarang dan } \\
\text { Surabaya). }\end{array}$ \\
\hline
\end{tabular}

Sumber :Diolah Oleh Penulis, 2018

Merujuk pada hasil analisis terhadap nilai penting warisan budaya Lasem, maka faktor-faktor tersebut jika dikombinasikan akan menghasilkan strategi sebagai berikut.

Tabel 3: Strategi Pengelolaan Warisan Budaya Lasem

\begin{tabular}{|l|l|l|l|}
\hline No & Strategi S/O & No & Strategi S/T \\
\hline 1. & $\begin{array}{l}\text { Masing-masing warisan budaya diusulkan } \\
\text { menjadi Cagar Budaya baik peringkat } \\
\text { Kota/Kabupaten, Propinsi, maupun } \\
\text { Nasional. }\end{array}$ & $\begin{array}{l}\text { Pendataan detil terhadap masing- } \\
\text { masing warisan budaya. }\end{array}$ \\
\hline $\begin{array}{l}\text { Apabila masing-masing telah berstatus } \\
\text { Cagar Budaya, khusus untuk Kawasan } \\
\text { Pecinan di Desa Dasun, Desa Gedong } \\
\text { Mulyo, dan Desa Karangturi dapat } \\
\text { diusulkan menjadi Kawasan Cagar Budaya. }\end{array}$ & $\begin{array}{l}\text { Pelibatan masyarakat secara aktif dalam } \\
\text { upaya pelestarian dan pemanfaatan warisan } \\
\text { budaya termasuk aktifitas pendataan. }\end{array}$ & 2. & $\begin{array}{l}\text { Pendaftaran bangunan-bangunan kuno } \\
\text { dan diberi label keterangan sebagai } \\
\text { bangunan warisan budaya. }\end{array}$ \\
\hline 3. & $\begin{array}{l}\text { Warisan Budaya Lasem dapat dijadikan } \\
\text { sebagai salah satu alternatif tujuan wisata } \\
\text { budaya, alam, dan agama. }\end{array}$ & 3. & $\begin{array}{l}\text { Pembangunan jalan lingkar sebagai } \\
\text { alternatif pengganti Jalan Lasem. }\end{array}$ \\
\hline
\end{tabular}




\begin{tabular}{|l|l|l|l|}
\hline 4. & $\begin{array}{l}\text { Penyusunan kalender yang berisi jadwal } \\
\text { acara-acara budaya di Lasem }\end{array}$ & 4. & $\begin{array}{l}\text { Perencanaan pembangunan fasilitas } \\
\text { umum yang berwawasan budaya dan } \\
\text { pelestarian. }\end{array}$ \\
\hline 5. & $\begin{array}{l}\text { Pembukaan jalur sungai sebagai salah satu } \\
\text { alternatif kegiatan penelusuran jalur } \\
\text { perdagangan Sungai Lasem }\end{array}$ & 5. & $\begin{array}{l}\text { Penambahan jenis transportasi yang } \\
\text { menghubungkan Lasem dengan kota- } \\
\text { kota besar terdekat, misalnya dengan } \\
\text { membuka kembali jalur kereta api. }\end{array}$ \\
\hline
\end{tabular}

\begin{tabular}{|c|c|c|c|}
\hline No. & Strategi W/O & No. & Strategi W/T \\
\hline 1. & $\begin{array}{l}\text { Pengelolaan warisan budaya } \\
\text { dengan masyarakat sebagai pelaku } \\
\text { utama. }\end{array}$ & 1. & $\begin{array}{l}\text { Masyarakat dilibatkan secara } \\
\text { langsung dalam pendataan warisan } \\
\text { budaya. } \\
\text { Pembentukan Badan Pengelola } \\
\text { Warisan Budaya Lasem. }\end{array}$ \\
\hline 2. & $\begin{array}{l}\text { Pemanfaatan bangunan-bangunan kuno } \\
\text { yang ada dengan maksimal sebagai } \\
\text { hunian, home stay, atau aktivitas } \\
\text { lainnya. }\end{array}$ & 2. & $\begin{array}{l}\text { Proyek-proyek } \\
\text { sarana umum diarahkan pada } \\
\text { perbaikan jalan-jalan di lingkungan } \\
\text { warisan budaya bukan pada } \\
\text { pelebaran jalan utama (Jalan } \\
\text { Lasem). }\end{array}$ \\
\hline & & & $\begin{array}{l}\text { Penataan jalur lalu lintas untuk } \\
\text { memecah kepadatan kendaraan di } \\
\text { suatu tempat. }\end{array}$ \\
\hline 3. & $\begin{array}{l}\text { Sosialisasi yang terus-menerus } \\
\text { mengenai nilai penting warisan budaya } \\
\text { Lasem. }\end{array}$ & 3. & $\begin{array}{l}\text { Meningkatkan pengetahuan dan } \\
\text { kreatifitas masyarakat untuk } \\
\text { mengembangkan warisan budaya } \\
\text { Lasem. }\end{array}$ \\
\hline 4. & $\begin{array}{l}\text { Pelatihan dan pembinaan tradisi, } \\
\text { kesenian tradisional, dan ekonomi } \\
\text { kreatif. }\end{array}$ & 4. & $\begin{array}{lrr}\text { Melibatkan } & \text { masyarakat } & \text { dalam } \\
\text { pemantauan } & \text { kegiatan } & \text { di } \\
\text { lingkungan warisan budaya. } & \\
\end{array}$ \\
\hline
\end{tabular}

Sumber :Diolah Oleh Penulis, 2018

Berdasarkan analisis SWOT terhadap nilai penting warisan budaya Lasem, maka strategi pengelolaan. Pengelolaan warisan budaya dapat mengacu Undang-Undang Republik Indonesia nomor 11 tahun 2010 tentang Cagar Budaya. Pengelolaan yang dimaksud dalam undang-undang tersebut adalah upaya terpadu untuk melindungi, mengembangkan, dan memanfaatkan Cagar Budaya melalui kebijakan pengaturan perencanaan, pelaksanaan, dan pengawasan untuk sebesar-besarnya kesejahteraan rakyat (Pasal 1 Nomor 21). Kebijakan pengelolaan Lasem yang ideal adalah berbasis pada masyarakat. Strategi pengelolaan ini dapat mengakomodasi beragam kepentingan masyarakat setempat. Salah satu alternatif yang dapat dilakukan adalah membentuk Lembaga Pengelola Warisan Budaya Lasem. 
Lembaga Pengelola yang dimaksudkan adalah sebuah lembaga yang menangani segala upaya pelestarian, pelindungan, dan pemanfaatan warisan budaya. Pelestarian adalahupaya dinamis untuk mempertahankan keberadaan Cagar Budaya dan nilainya dengan cara melindungi, mengembangkan, dan memanfaatkannya (Pasal 1 Nomor 22). Pelindungan adalah upaya mencegah dan menanggulangi dari kerusakan, kehancuran, atau kemusnahan dengan cara Penyelamatan, Pengamanan, Zonasi, Pemeliharaan, dan Pemugaran Cagar Budaya (Pasal 1 Nomor 23). Pelindungan yang dimaksud adalah menjaga agar warisan budaya tetap ada untuk dapat diteruskan pada generasi berikutnya. Pemanfaatan adalah Pemanfaatan adalah pendayagunaan Cagar Budaya untuk kepentingan sebesar-besarnya kesejahteraan rakyat dengan tetap mempertahankan kelestariannya (Pasal 1 Nomor 33).

Lembaga Pengelola yang dimaksud berisi orang-orang dengan kapasitas tertentu, namun merupakan masyarakat Lasem baik yang tinggal di Lasem maupun yang sudah berdomisili di wilayah lain. Namun diupayakan diambil dari masyarakat yang bermukim di Lasem agar kerja lembaga ini lebih optimal baik dalam perencanaan, pelaksanaan, maupun evaluasinya. Struktur organisasi Lembaga Pengelola dapat digambarkan sebagai berikut:

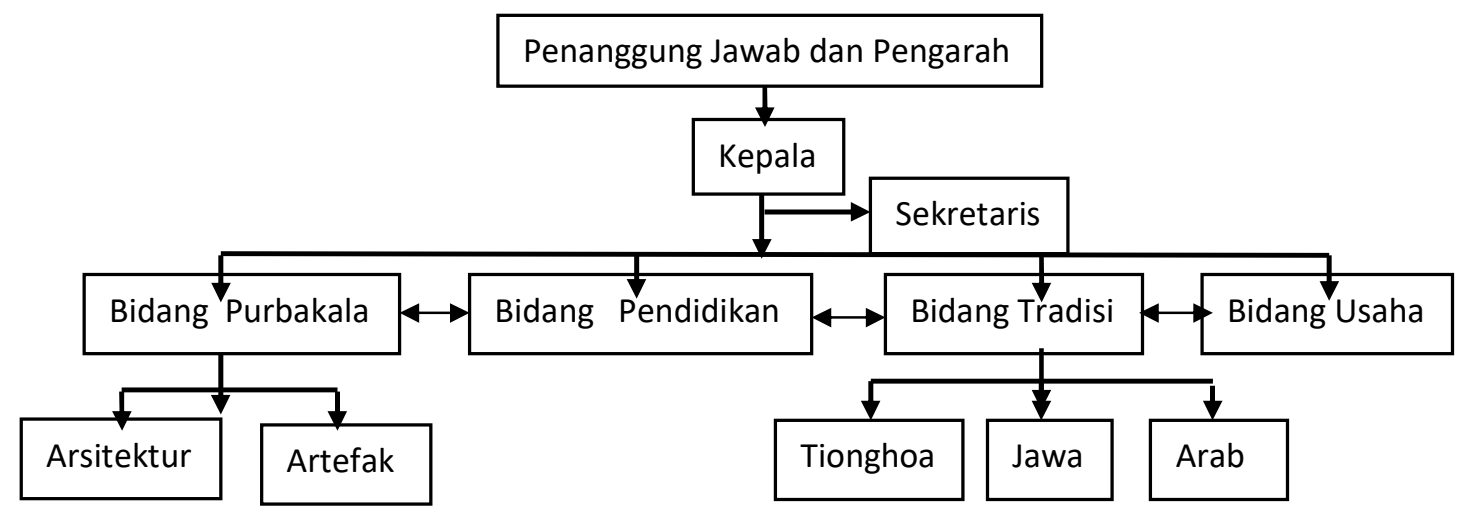

Gambar 3: Struktur Organisasi Lembaga Pengelola Sumber :Diolah oleh penulis, 2018

Lembaga Pengelola yang dibentuk memiliki tugas yang cukup berat karena terdapat dua kepentingan yang saling bertentangan. Di satu sisi mereka harus menjaga kelestarian dan keberadaan warisan budaya. Di sisi yang lain mereka harus mengakomodasi kemajuan dan kepentingan masyarakat yang ada saat ini. Tugas berat yang menanti harus dapat ditangani dengan baik sehingga mendapatkan penyelesaian yang mengakomodasi berbagai 
kepentingan yang saling berbenturan. Untuk itulah dibutuhkan orang-orang dengan kemampusan tertentu agar tujuan Lembaga Pengelola dapat tercapai. Gambaran kemampuan yang dibutuhkan untuk mengisi Badan Pengelola sebagai berikut:

Tabel 4: Kemampuan yang dibutuhkan dalam Lembaga Pengelola

\begin{tabular}{|c|c|c|c|}
\hline 1. & Penanggung Jawab dan Pengarah & $:$ & Pemimpin daerah yang memiliki otoritas kekuasaan \\
\hline \multirow[t]{4}{*}{2.} & Kepala & $:$ & $\begin{array}{l}\text { Dapat diterima oleh seluruh kalangan masyarakat } \\
\text { Lasem. }\end{array}$ \\
\hline & & & $\begin{array}{l}\text { Memiliki kemampuan memimpin dan dapat } \\
\text { mengkomunikasikan tujuan Badan Pengelolan } \\
\text { kepada pemerintah. }\end{array}$ \\
\hline & & & $\begin{array}{l}\text { Memiliki kemampuan berpikir strategis dan sensitif } \\
\text { terhadap kekinian (Kebutuhan dan kecenderungan). }\end{array}$ \\
\hline & & & $\begin{array}{l}\text { Memiliki pengetahuan tentang sejarah kehidupan } \\
\text { Lasem. }\end{array}$ \\
\hline 3. & Sekretaris & $:$ & Memiliki kemampuan administrasi yang baik \\
\hline \multirow[t]{6}{*}{4.} & Bidang Purbakala & $:$ & Memiliki latar belakang Ilmu Arkeologi. \\
\hline & & & Memiliki pengetahuan sejarah kebudayaan Lasem. \\
\hline & Sub Bidang Arsitektur & $:$ & $\begin{array}{l}\text { Memiliki latar belakang Ilmu Arsiterktur dan tata } \\
\text { ruang kota. }\end{array}$ \\
\hline & & & $\begin{array}{l}\text { Memiliki kemampuan } \\
\text { pengembangan dan pemanfaatan } \\
\text { bangunan kuno yang ada di Lasem. }\end{array}$ \\
\hline & & & $\begin{array}{l}\text { Memiliki pengetahuan mengenai sejarah } \\
\text { kebudayaan di Lasem. }\end{array}$ \\
\hline & Sub Bidang Artefak & $:$ & $\begin{array}{l}\text { Memiliki pengetahuan tentang sejarah kebudayaan } \\
\text { Indonesia dan Lasem. } \\
\text { Orang dengan latar belakang Ilmu Arkeologi. }\end{array}$ \\
\hline 5. & $\begin{array}{l}\text { Bidang Tradisi: } \\
\text { a. Tradisi Jawa } \\
\text { b. Tradisi Tionghoa } \\
\text { c. }\end{array}$ & $:$ & $\begin{array}{l}\text { Memiliki pengetahuan tentang tradisi yang ada di } \\
\text { Lasem. Mengingat di Lasem terdapat tiga etnis } \\
\text { yaitu Jawa, Tionghoa, dan Arab maka pada bidang } \\
\text { ini terdapat tiga kepala sub bidang. }\end{array}$ \\
\hline \multirow[t]{2}{*}{6.} & Bidang Pendidikan & $:$ & $\begin{array}{l}\text { Memiliki dengan kemampuan berkomunikasi } \\
\text { dengan baik di depan forum dan memiliki } \\
\text { pengetahuan mendalam tentang nilai penting } \\
\text { warisan budaya Lasem. }\end{array}$ \\
\hline & & & $\begin{array}{l}\text { Memiliki kemampuan pendekatan pada segala } \\
\text { lapisan masyarakat. }\end{array}$ \\
\hline 7. & Kepala Bidang Usaha & $:$ & $\begin{array}{l}\text { Memiliki kemampuan berpikir kreatif } \\
\text { memanfaatkan potensi Lasem } \\
\text { sebagai satu kesatuan. }\end{array}$ \\
\hline
\end{tabular}

Sumber : Diolah Oleh Penulis, 2018

\section{KESIMPULAN DAN SARAN}

\section{A. KESIMPULAN}

Berdasarkan pada analisis nilai penting dan SWOT warisan budaya Lasem, dihasilkan sebuah kesimpulan bahwa warisan budaya Lasem memiliki nilai penting bagi 
masyarakat masa lalu, masa sekarang, dan masa yang akan datang. Warisan budaya Lasem memiliki potensi untuk dimanfaatkan dan dikelola oleh masyarakat Lasem. Potensi yang dimiliki warisan budaya Lasem saat ini banyak yang rusak dan hilang dengan berbagai alasan.

Saat ini, sebagian masyarakat Lasem telah memanfaatkan keberadaan warisan budaya. Pemanfaatan yang dilakukan hanya bersifat kelompok-kelompok kecil sesuai bidang kemampuan masing-masing. Misalnya LSM dengan ketertarikan mereka pada bidang tertentu, pengusaha batik dengan produksi dan pemasarannya. Namun tidak sedikit masyarakat yang belum mengetahui nilai penting warisan budayanya. Ketidaktahuan ini berimbas pada pembiaran dan pengabaian warisan budaya sehingga banyak warisan budaya yang rusak bahkan hilang. Oleh karena itu, perlu dibentuk sebuah Badan Pengelola yang nantinya akan mengekomodasi berbagai kepentingan masyarakat terhadap pengelolaan warisan budaya.

Lembaga pengelola bekerja dengan dasar hukum dan pendampingan instansi pemerintah yang terkait dengan pelestarian warisan budaya. Pengelolaan diserahkan pada Badan yang mewakili seluruh masyarakat Lasem, sementara pemerintah bertanggung jawab untuk memfasilitasi kebutuhan-kebutuhan yang berhubungan dengan pelestarian warisan budaya. Pemerintah juga bertanggung jawab untuk melakukan pendampingan dan pemantauan serta memberikan informasi kepada masyarakat luas mengenai kegiatan pelestarian dengan jadwal-jadwal budaya Lasem setiap tahunnya.

\section{B. SARAN}

Saran dalam penelitian ini terdapat tiga dengan beberapa point. Saran yang diajukan berkenaan dengan masalah perundang-undangan, sarana-prasarana, dan sumber daya manusia.

\section{B.1. Perundang-Undangan}

a. Pemberian status hukum pada warisan budaya baik peringkat lokal maupun nasional yang sesuai dengan UU RI nomor 11 Tahun 2010.

b. Penyusunan peraturan bagi Lembaga Pengelola yang akan dibentuk, sehingga memiliki dasar hukum dalam bekerja.

c. Penyusunan standar prosedur operasional (tahapan kerja) Lembaga Pengelolaan. 


\section{B.2. Sarana-Prasarana}

a. Pembangunan dan perbaikan jalan, serta pengaturan jalur menuju tempat-tempat warisan budaya yang tersebar di wilayah Lasem.

b. Pemanfaatan bangunan-bangunan lama untuk home stay bagi para pendatang yang perlu bermalam di Lasem.

c. Penyediaan tempat-tempat kuliner khas Lasem.

d. Penambahan moda transportasi umum yang dapat menjangkau Lasem dari kota besar terdekat seperti Semarang dan Surabaya. Misalnya dengan menghidupkan kembali transportasi Kereta Api.

e. Menghidupkan kembali jalur Sungai Babagan untuk penelusuran jalur perdagangan melalui sungai di Lasem.

\section{B.3. Sumber Daya Manusia}

a. Sosialisasi yang bertujuan untuk meningkatkan pemahaman seluruh kalangan masyarakat Lasem pada warisan budaya mereka.

b. Meningkatkan keterlibatan masyarakat Lasem dalam pengelolaan warisan budaya.

c. Mempersiapkan masyarakat menerima kedatangan masyarakat luar yang ingin mengunjungi Lasem dengan segala keunikan yang dimiliki.

\section{DAFTAR PUSTAKA}

Aksa, La Ode Muhammad. (2004). "Integritas Sumberdaya Budaya Arkeologi dan Pembangunan ". http://www.arkeologi.com

Anonim. (2017). Rembang Dalam Angka. Rembang: Badan Perhitungan Statistik.

Anonim. (2013). Undang-Undang Republik Indonesia Nomor 11 Tahun 2010. Klaten: Balai Pelestarian Cagar Budaya Jawa Tengah.

Anonim. (2015). Profil Kebudayaan, Pariwisata, Pemuda, dan Olah Raga Kabupaten Rembang. Rembang: Disbudparpora.

Graff, H.J De and Th. Pigeaud. (1984). "Chinese Muslim in Java in the 15th and 16th Centuries”. Monash Paper on Southeast Asia no. 12. North Melborne: Ruskin Press.

Graff, H.J De. (1986). Puncak Kekuasaan Mataram Politik Ekspansi Sultan Agung. Jakarta: Grafiti Press.

Graaf, H.J De. (1987). Runtuhnya Istana Mataram. Jakarta: Grafiti Press. 
Jurnal Planologi Vol. 15, No. 2, Oktober 2018

Available : http://jurnal.unissula.ac.id/index.php/psa

Graaf, H.J. De. (1987). Disintegrasi Mataram Di Bawah Amangkurat I. Jakarta: Grafitipers

Hardjowardojo, R. Pitono. (1965). Pararaton. Malang: PT. Bhatrara.

Hartono, Samuel. (2010). Lasem Kota Kuno Di Pantai Utara Jawa Yang Bernuansa China. Surabaya: Universitas Kristen Petra.

Karsono, R. (1920). Babad Lasem. Tidak Diterbitkan

Kasnowihardjo, Gunadi. (2013). Penelitian Kubur Prasejarah Di Situs Leran, Kecamatan Sluke, Kabupaten Rembang, Provinsi Jawa Tengah. Yogyakarta :Balai Arkeologi.

Kridalaksana, Harimurti. (1996). Pembentukan Kata dalam Bahasa Indonesia. Jakarta :Gramedia Pustaka Utama

Kwan, William. (2010). Eksplorasi Sejarah Batik Lasem. Jakarta: Institut Pluralisme Indonesia

Purbasari, Riris, (ed). (2011). Identifikasi Potensi Perairan Lasem Kabupaten Rembang. Klaten: Balai Pelestarian Cagar Budaya Jawa Tengah.

Pratiwo. (2010). Arsitektur Tradisional Tionghoa dan Perkembangan Kota. Yogyakarta: Penerbit Ombak

Riana, I Ketut. (2009). Nagarakrtagama: Masa Keemasan Majapahit. Jakarta: Kompas.

Utomo, Bambang Budi. (2009). Majapahit dalam Lintas Pelayaran dan Perdagangan Nusantara. Berkala Arkeologi, 29 (2), 1-8. 